SEJODR

\title{
Reasons for seeking orthodontic treatment in Lahore population: A cross-sectional survey in a low-income country
}

\author{
Faiz Rasul ${ }^{1}$; Muhammad Waheed ul Hamid ${ }^{2}$; Mehwish Tariq ${ }^{3}$; Zainab Rizvi ${ }^{1}$; Muhammad Ilyas ${ }^{2}$; Shabbir Hussain Shab ${ }^{2}$ \\ 1. Department of Oral Pathology de' Montmorency College of Dentistry, Lahore \\ 2. Department of Orthodontics de' Montmorency College of Dentistry, Lahore \\ 3. de' Montmorency College of Dentistry, Lahore
}

\begin{abstract}
Introduction: Poor esthetics, dysfunction and discomfort are the key reasons for seeking orthodontic treatment across the world as reported by many researchers. This paper presents the causative factor for seeking orthodontic treatment in the patients who are visiting Punjab Dental Hospital of a populous city Lahore (de' Montmorency College of Dentistry) in local settings and associating these reasons with demographic characteristics.

Objective: Aim of this cross-sectional survey was to explore the reasons for seeking orthodontic treatment among individuals who are visiting PDH. Materials and methods: This study was carried out in Punjab Dental Hospital (PDH) after the approval of the Institutional Review Board (IRB) on a sample of 98 individuals having malocclusion assessed with Angle's classification of the malocclusion. We chose simple random sampling. A self-structure questionnaire was designed to get data by the principal investigator after taking verbal and written consent. Descriptive statistics were calculated using SPSS 21. Chi-square test of association was applied to associate reasons with different demographic variables. P-value $<0.05$ was taken as significant.

Results: Female respondents were more in number than males. Around one-third of respondents (30.6\%) had a monthly income of less than 25000 PKR (\$170). Esthetics was the primary reason for seeking orthodontic treatment. The most common type of malocclusion was the Class II malocclusion. Statistically significant factors that emerged in this study that turned into reasons for seeking orthodontic treatment were hurdles in marriage, referral by a general dentist, motivation by parents, self-esteem and speech problems.

Conclusion: In conclusion, patients seek orthodontic treatment mainly to enhance facial esthetics and self-confidence, motivation by the parents, and social acceptability.

Rasul F., ul Hamid M., Tariq M., Rizvi Z., Ilyas M., Shah SH. Reasons for seeking orthodontic treatment in Lahore population: A cross-sectional survey in a lowincome country. South Eur J Orthod Dentofac Res. 2019;6(2):35-39.
\end{abstract}

May 14, 2019; Revised: September 7, 2019; Published: October 152019

\section{INTRODUCTION}

Malocclusion defined as a handicapping dentofacial anomaly by the WHO refers to abnormal occlusion and/or disturbed craniofacial relationships, which may affect esthetic appearance, function, facial harmony and psychosocial

Corresponding Author:

Faiz Rasul

Department of Oral Pathology de' Montmorency

College of Dentistry,

Lahore Pakistan.

e-mail: bayfaiz871@gmail.com well-being. ${ }^{1}$ According to Angle's classification of the malocclusion, the mesiobuccal cusp of maxillary first molar occludes with a buccal groove of mandibular first molar in Class I. Further, the mandibular first molar was distally positioned in Class II malocclusion and mesially positioned in Class III malocclusion relative to the upper first molar. ${ }^{2}$ Malocclusion affects the emotional, psychological and physical well-being of an individual. The unappealing aesthetic is one of the most important problems of malocclusion as facial appearance, self-esteem and quality of life are inauspiciously affected by it. Changes in speech pattern, chewing, breathing, 
swallowing, posture, TMJ disorders and pain has been frequently observed in children suffering from malocclusion. It has been observed that the urge to look alluring, selfperception of dental appearance, dignity, gender, age and peer group norms is the reason for orthodontic treatment. ${ }^{3}$ The factors determining the health-seeking behavior may be seen in various contexts: physical, socio-economic, cultural and political. Therefore the utilization of a health care system, public or private, formal or non-formal, may depend on sociodemographic factors, social structures, level of education, cultural beliefs and practices, gender discrimination, status of women, economic and political systems environmental conditions, and the disease pattern and health care system itself. ${ }^{4}$ Esthetic is one of the most common reasons for seeking orthodontic treatment across the world, as reported by many researches. ${ }^{5-12}$ Parents' motivation (the second most common reason) is also the rational why patients are in pursuit of orthodontic treatment as parents/guardians are most concerned about their child's appearance. ${ }^{13}$ Misaligned teeth are considered social stigma, as many patients have been teased by their fellows in their teens. More than half of the population in New Zealand reported that maloccluded teeth had affected their social relationships due to unsightly appearance. It has been observed that people hide their faces in public because crooked teeth make them feel socially embarrassed and have also been bullied publicly. ${ }^{14,15}$ Difficulty in biting and chewing is another reason for seeking professional help seen in many regions of the world, according to Leena Nurminen (1999). ${ }^{16}$ The objective of this study was to determine the causative factor for seeking orthodontic treatment in the patients who are visiting Punjab Dental Hospital Lahore (de 'Montmorency College of dentistry) in local settings and associating these reasons with demographic characteristics.

\section{MATERIALS AND METHODS}

We conducted a cross-sectional study in Punjab Dental Hospital, which is affiliated with de 'Montmorency College of Dentistry, Lahore, after approval of the Institutional Review Board of this institute. A self-structured questionnaire having 21 closed-ended questions was designed. The selfstructured questionnaire consisted of two parts: the first part was regarding demographic data such as age, gender, socioeconomic status, educational level, monthly income and type of malocclusion present. The second part comprised of questions related to reasons for seeking orthodontic treatment in the public hospital, such as dissatisfaction with facial appearance, dysfunction, motivation and social stigma. Data collection was completed for six months, i.e., October 2018 to March 2019, through simple random sampling from the Orthodontic department. A total of 98 respondents having malocclusion of both gender and age 11 to 44 years old were included in this study. Individuals who did not give consent and have any systemic disease were excluded from this study. Verbal and written consent was taken from the respondent to answer this 3-4 minutes duration questionnaire to be filled by the principal investigator. Angle's classification was used to assess the type of malocclusion. After data collection, data were entered into SPSS 21. Descriptive statistics were used to calculate percentages and frequency for variables such as demographic and reason for seeking orthodontic treatment. Chi-square test of association was applied to associate reasons with different demographic variables. P-value $<0.05$ was taken as significant.

\section{RESULTS}

Table 1. Descriptive statistics in frequency and percentage among individuals seeking orthodontic treatment in Punjab Dental Hospital n (98)

\begin{tabular}{|c|c|c|}
\hline Demographic characteristics & Frequency $(\mathbf{n})$ & Percentage (\%) \\
\hline \multicolumn{3}{|l|}{ Age } \\
\hline $11-14$ & 28 & 28.6 \\
\hline $15-17$ & 22 & 22.4 \\
\hline $18-21$ & 23 & 23.5 \\
\hline $22-34$ & 24 & 24.5 \\
\hline $35-44$ & 1 & 1 \\
\hline \multicolumn{3}{|l|}{ Gender } \\
\hline Male & 37 & 37.8 \\
\hline Female & 61 & 62.2 \\
\hline \multicolumn{3}{|l|}{ Education } \\
\hline Primary & 21.4 & 21.4 \\
\hline Middle & 13 & 13.3 \\
\hline Secondary & 22 & 22.4 \\
\hline Higher secondary & 22 & 22.4 \\
\hline Graduation & 20 & 20.4 \\
\hline \multicolumn{3}{|l|}{ Monthly income } \\
\hline$<25000$ & 30 & 30.6 \\
\hline $26000-50,000$ & 13 & 13.3 \\
\hline $51,000-100,000$ & 26 & 26.5 \\
\hline$>100,000$ & 15 & 15.3 \\
\hline \multicolumn{3}{|l|}{ Type of malocclusion } \\
\hline Class-I & 30 & 30.6 \\
\hline Class-II & 64.3 & 64.3 \\
\hline Class-III & 5 & 5.1 \\
\hline
\end{tabular}


Table 2. Reasons for orthodontic treatment-seeking behavior among individuals seeking orthodontic treatment in Punjab Dental Hospital n (98)

\begin{tabular}{|c|c|c|c|c|}
\hline Sr.No & Reasons for orthodontic treat & nent-seeking & $\begin{array}{l}\text { Frequency } \\
(\mathbf{n})\end{array}$ & $\begin{array}{l}\text { Percentage } \\
(\%)\end{array}$ \\
\hline \multirow[t]{3}{*}{1} & \multirow[t]{3}{*}{ Esthetics } & Yes & 87 & 88.8 \\
\hline & & No & 10 & 10.2 \\
\hline & & Don't Know & 1 & 1 \\
\hline \multirow[t]{3}{*}{2} & \multirow[t]{3}{*}{ Motivated by parents } & Yes & 76 & 77.6 \\
\hline & & No & 22 & 22.4 \\
\hline & & Don't know & 0 & 0 \\
\hline \multirow[t]{3}{*}{3} & \multirow[t]{3}{*}{ Pride/status symbol } & Yes & 26 & 26.5 \\
\hline & & No & 66 & 67.3 \\
\hline & & Don't know & 6 & 6.1 \\
\hline \multirow[t]{3}{*}{4} & \multirow[t]{3}{*}{ Feel discomfort } & Yes & 60 & 61.2 \\
\hline & & No & 37 & 37.8 \\
\hline & & Don't know & 1 & 1 \\
\hline \multirow[t]{3}{*}{5} & \multirow[t]{3}{*}{ Problem while speaking } & Yes & 21 & 21.4 \\
\hline & & No & 77 & 78.6 \\
\hline & & Don't know & 0 & 0 \\
\hline \multirow[t]{3}{*}{6} & \multirow{3}{*}{ Problem while mastication } & Yes & 18 & 18.4 \\
\hline & & No & 80 & 81.6 \\
\hline & & Don't know & 0 & 0 \\
\hline \multirow[t]{3}{*}{7} & \multirow[t]{3}{*}{ Referred by a general dentist } & Yes & 23 & 23.5 \\
\hline & & No & 75 & 76.5 \\
\hline & & Don't know & 0 & 0 \\
\hline \multirow[t]{3}{*}{8} & \multirow[t]{3}{*}{ Hurdle in marriage } & Yes & 39 & 39.8 \\
\hline & & No & 51 & 52 \\
\hline & & Don't know & 8 & 8.2 \\
\hline \multirow[t]{3}{*}{9} & \multirow[t]{3}{*}{ Hurdle in getting job } & Yes & 33 & 33.7 \\
\hline & & No & 53 & 54.1 \\
\hline & & Don't know & 12 & 12.2 \\
\hline \multirow[t]{3}{*}{10} & \multirow[t]{3}{*}{ Teased by people } & Yes & 42 & 42.9 \\
\hline & & No & 56 & 57.1 \\
\hline & & Don't know & 0 & 0 \\
\hline \multirow[t]{3}{*}{11} & Motivated by parents \& siblings & Yes & 81 & 82.7 \\
\hline & & No & 17 & 17.3 \\
\hline & & Don't know & 0 & 0 \\
\hline 12 & Motivated by relatives $\&$ friends & Yes & 58 & 59.2 \\
\hline & & No & 39 & 39.8 \\
\hline & & Don't know & 1 & 1 \\
\hline 13 & Improve function in society & Yes & 87 & 88.8 \\
\hline & & No & 5 & 5.1 \\
\hline & & Don't know & 6 & 6.1 \\
\hline 14 & $\begin{array}{l}\text { Relatives \& friends gone } \\
\text { through Orthodontic treatment }\end{array}$ & Yes & 41 & 41.8 \\
\hline & & No & 57 & 58.2 \\
\hline & & Don't know & 0 & 0 \\
\hline 15 & Will build confidence & Yes & 90 & 91.8 \\
\hline & & No & 8 & 8.2 \\
\hline & & Don't know & 0 & 0 \\
\hline 16 & $\begin{array}{l}\text { Will help get better jobs in } \\
\text { the future }\end{array}$ & Yes & 45 & 45.9 \\
\hline & & No & 42 & 42.9 \\
\hline & & Don't know & 11 & 11.2 \\
\hline 12 & Motivated by relatives $\&$ friends & Yes & 58 & 59.2 \\
\hline & & No & 39 & 39.8 \\
\hline & & Don't know & 1 & 1 \\
\hline
\end{tabular}

Table 3. Cross-tabulation between the type of malocclusion and reasons for Orthodontic treatment-seeking behavior in Punjab Dental Hospital n (98)

\begin{tabular}{|c|c|c|c|c|c|}
\hline Sr.No & Variable & \multicolumn{3}{|c|}{ Health seeking behavior } & $P$-value \\
\hline \multirow[t]{6}{*}{1} & Type of malocclusion & \multicolumn{4}{|c|}{ Malaligned teeth hurdle in marriage } \\
\hline & & Yes & No & Total & 0.006 \\
\hline & Class-1 & 8 & 22 & 30 & \\
\hline & Class-11 & 11 & 52 & 63 & \\
\hline & Class-111 & 4 & 1 & 05 & \\
\hline & Total & 23 & 75 & 98 & \\
\hline \multirow[t]{6}{*}{2} & Type of malocclusion & \multicolumn{4}{|c|}{ Speaking problem } \\
\hline & & Yes & No & Total & 0.005 \\
\hline & Class-1 & 5 & 25 & 30 & \\
\hline & Class-11 & 12 & 51 & 63 & \\
\hline & Class-111 & 4 & 1 & 5 & \\
\hline & Total & 21 & 77 & 98 & \\
\hline \multirow[t]{6}{*}{3} & Type of malocclusion & \multicolumn{4}{|c|}{ Referred by a general dentist } \\
\hline & & Yes & No & Total & 0.006 \\
\hline & Class-1 & 8 & 22 & 30 & \\
\hline & Class-11 & 11 & 52 & 63 & \\
\hline & Class-111 & 4 & 1 & 5 & \\
\hline & Total & 23 & 75 & 98 & \\
\hline \multirow[t]{6}{*}{4} & Type of malocclusion & \multicolumn{4}{|c|}{ ODT seeking will improve self-esteem } \\
\hline & & Yes & No & Total & 0.007 \\
\hline & Class-1 & 26 & 4 & 30 & \\
\hline & Class-11 & 61 & 2 & 63 & \\
\hline & Class-111 & 3 & 2 & 5 & \\
\hline & Total & 90 & 8 & 98 & \\
\hline \multirow[t]{6}{*}{4} & Type of malocclusion & \multicolumn{4}{|c|}{ Motivated by parents } \\
\hline & & Yes & No & Total & 0.054 \\
\hline & Class-1 & 19 & 11 & 30 & \\
\hline & Class-11 & 52 & 11 & 63 & \\
\hline & Class-111 & 5 & 0 & 05 & \\
\hline & Total & 76 & 22 & 98 & \\
\hline
\end{tabular}

\section{DISCUSSION}

Women are more inclined towards self-perception and selfconsciousness, especially when it comes to beauty. ${ }^{17}$ Our current study also concludes the desire of females towards orthodontic treatment as compared to males. However, it slightly contradicts the study conducted by Ahmed Al Fawzan in 2013 as it does not show a significant difference between males and females regarding orthodontic treatment. ${ }^{10}$ Parmjit Singh did another study in the UK in 2016, where he found out of total respondents, $73 \%$ are females, ${ }^{7}$ which shows female concerns more as compared to male as far as orthodontic treatment behavior is concerned. Abdullah also found female predominance in his pilot study as $61 \%$ female as compared to male which is similar to our result $62.2 \%$, however most common age group in his study was $13-19$ years old which was $67 \%,{ }^{11}$ in current study 11-21 year age group was $74.5 \%$ which is showing that health-seeking behavior is much more common in teenage and adolescent as compared to others as results depicted around 
$25,5 \%$ respondents were categorized into age group of $22-44$ years old. In our study, $64.3 \%$ of patients have Class II malocclusion followed by Class I (30\%) and Class III (5\%). This result is dissimilar to the study conducted by Pandey in 2018 in Nepal as it concludes $61.92 \%$ Class I, 33.47\% Class II and 4.60\% Class III. ${ }^{18}$ In current study most common reason of orthodontic treatment-seeking was found esthetic which is $88.8 \%$ which is quite similar to the studies conducted in different countries such as dos Santos Oliveira et al. (2018) 93\%, Singh (2016) around 86\%, ${ }^{7}$ Al Fawzan (2013) 86\%, ${ }^{10}$ Kong (2018) 68.8\% Abdullah (2001) 65\%, ${ }^{11}$ Philips (1998) 60\% ${ }^{9}$ and Hassan (2006) 56.8\%.6 In another study conducted in Brazil, $72 \%$ of the schoolchildren with an extremely low socio-economic level were dissatisfied with the appearance of their front teeth - due mainly to alignment (46.5\%). ${ }^{11}$ The patriarchal family structure is a norm in Sub-continent; the father act as head of a family circle and in charge of discipline. ${ }^{19}$ As a child grows, parents/guardians play a dominating role in upbringing and are the most influential people in one's life. ${ }^{20}$ According to our study, $76 \%$ of respondents are motivated by their parents regarding orthodontic treatment. This result is distinct from Ahmed Al-Fawzan (2013), where parents motivated only $16 \%$ of respondents. ${ }^{10}$ Wędrychowska-Szulc and Syryńska did a study in Brazil (2009) also concludes that parents motivate $77 \%$ of respondents. ${ }^{13}$ This result is similar to our study. By this local system and culture, we can say that patients are not self-motivated, their parents/guardians motivate them. Bullying is endemic among school children, which leads to bad psychological health, under-confident and submissive nature, ${ }^{20} 42.9 \%$ of patients in our study are intimidated by others due to misaligned teeth in their teenage. A child's psychological profile may influence treatment demand. ${ }^{15,17}$ In 2009, another study was done by Marques in Brazil and the result of this study is much similar to us regarding people with misaligned teeth teased by people $(60 \%){ }^{14}$ The majority of the respondents in our study have low socioeconomic status, as $30.6 \%$ of individuals have a monthly family income of less than 25000 (PKR). In census 2017 Lahore was declared second-most populous city of Pakistan with 11.2 million inhabitants in urban area, ${ }^{21}$ in such a dense populous city Punjab Dental Hospital which collaborates with de 'Montmorency College of Dentistry is the only health care center in Lahore where people have treatment facilities with free consultancy and nominal charges of the procedure. Individuals get a long appointment schedule due to limitation in human resource and constrain of the infrastructure, due to this reason most of the individual who visits this hospital have less income and underprivileged as result of our study also depicted.
Teeth are articulating organs for the formation of sound and mastication; missing or misaligned teeth lead to altered voice production, difficulty in chewing and TMJ disorders. According to our study, $21.4 \%$ of respondents find difficulty while speaking and $18.4 \%$ feels difficulty in mastication. While the study by Ahmed Al Fawzan concludes, only $1 \%$ of respondents are seeking orthodontic treatment because they feel difficulty in chewing and speech; ${ }^{10} 2 \%$ of respondents in the UK seek orthodontic treatment due to speech problem in the UK as reported by Singh. ${ }^{7}$ The results of our study are quite dissimilar to Nurminen (1999). ${ }^{16}$ In Finland, where $68 \%$ of respondents feel difficulty in chewing. ${ }^{16}$ Around $91.8 \%$ of people in our study confess their confidence level will build after this treatment while it is $82 \%$ in KSA by Ahmed Al Fawzan ${ }^{7}$ and $52 \%$ in the UK by Parmjit Singh. ${ }^{10}$ Certain limitations of the study were also noted, such as small sample size and individuals who are visiting public hospitals belonged to low socio-economic position. There is a need to conduct a study with a large sample size to determine crucial factors for seeking orthodontic treatment in local population.

\section{CONCLUSION}

The results of this study show that the primary reason for seeking orthodontic treatment among individuals who are visiting a public hospital in Lahore is esthetic. Although the majority of the individuals belong to the low-income group, yet demand in the orthodontic treatment in a low socio-economic group is high. Lahore is an overcrowded city, and there is only one public hospital where the possibility of free treatment is available but with the exhausting appointment system. There is a need to start orthodontictreatmentineachtertiary teachinghospitalandDistrict headquarter hospitals in order to reduce the burden of diseases

\section{CONFLICT OF INTEREST}

There is no conflict of interest in this study.

\section{ACKNOWLEDGMENTS}

We are grateful to the individuals who participated in this research. We are also thankful to the Principal de' Montmorency College of Dentistry and Medical Superintendent of Punjab Dental Hospital for conducting this cross-sectional survey. 


\section{REFERENCES}

1. Isaia B, Ravarotto M, Finotti P, Nogara M, Piran G, Gamberini J, Biz C, Masiero S, Frizziero A. Analysis of Dental Malocclusion and Neuromotor Control in Young Healthy Subjects through New Evaluation Tools. J. Funct. Morphol. Kinesiol. 2019; 4(1):5.

2. Alkan Ö, Kaya Y, Alkan EA, Keskin S, Cochran DL. Assessment of Gingival Biotype and Keratinized Gingival Width of Maxillary Anterior Region in Individuals with Different Types of Malocclusion. Turk J Orthod. 2018;31(1):13-20.

3. Chahal N, Rana M, Dhawan A, Gulia S. Assessment of Frequency of Occurrence of Malocclusion among Known Paediatric Population: A Clinical Study. J Adv Med Dent Scie Res 2018;6(8):37-39.

4. Shaikh BT, Hatcher J. Health seeking behaviour and health service utilization in Pakistan: challenging the policy makers. J Public Health (Oxf). 2005;27(1):49-54.

5. dos Santos Oliveira R, Flório FM, Oliveira AM. Self-Perception of Brazilian Adolescents who need Orthodontic Treatment. Pesquisa Brasileira em Odontopediatria e Clinica Integrada. 2018;18(1):3729.

6. Hassan N, Rasool G, Nausheen A, Rahman S, Hussain T. Patient and parent motivation for orthodontic treatment. Journal of Khyber College of Dentistry (JKCD). 2016; 6(2): 11-15.

7. Singh P. Adult orthodontic patients in primary care and their motivation for seeking treatment. Orthodontic Update. 2016 Apr 2;9(2):69-72. Accessesd on October 2019 (https://tendental.com/wp-content/uploads/2019/04/2016-Publication-4.pdf)

8. dos Santos Letieri A, Fernandez CC, Lima SO, Maia LC, Coqueiro RS, Pithon MM. Age and aesthetics perception related to different types of orthodontic devices. Is there a relationship? J World Fed Orthod. 2018 Mar 1;7(1):29-33.

9. Phillips C, Bennett ME, Broder HL. Dentofacial disharmony: psychological status of patients seeking treatment consultation. Angle Orthod. 1998;68(6):547-56.

10. Al Fawzan A, Al Fawzan A. Reasons for seeking orthodontic treatment in Qassim region: a Pilot Study. Int Dent J Stud Res. 2013;1:58-62.
11. Abdullah AA, Yassin ZM, Zamzam N. Reasons For Seeking Orthodontic Treatment A Pilot Study. Annals of Dentistry University of Malaya. 2001;8(1):13-9.

12. Kong YY, Ghazali H, Hassan WN. Orthodontic treatment need and outcome at University of Malaya. Annals of Dentistry University of Malaya. 2018;19(1):1-0.

13. Wedrychowska-Szulc B, Syryńska M. Patient and parent motivation for orthodontic treatment--a questionnaire study. Eur J Orthod. 2010;32(4):447-52.

14. M Marques LS, Ramos-Jorge ML, Ramos-Jorge J, Pereira LJ, Paiva SM, Pordeus LA. Self-perception regarding the need for orthodontic treatment among impoverished schoolchildren in Brazil. Eur J Paediatr Dent. 2009;10(3):125-30.

15. Smith L, Wong L, Phemister R, Blanch K, Jack H, Fowler P, Antoun J, Foster Page L. "Why, why, why do I have such big teeth, why?" Low socio-economic status and access to orthodontic treatment. New Zealand Dental Journal. 2018;114 (2):64-72.

16. Nurminen L, Pietilä T, Vinkka-Puhakka H. Motivation for and satisfaction with orthodontic-surgical treatment: a retrospective study of 28 patients. Eur J Orthod. 1999;21(1):79-87.

17. Etcoff NL, Stock S, Haley LE, Vickery SA, House DM. Cosmetics as a feature of the extended human phenotype: Modulation of the perception of biologically important facial signals. PloS one. 2011;6(10):e25656.

18. Pandey BR, Singh SK, Singh R, Mishra R, Mishra S, Ghart B. Pattern of Malocclusion in PatientSeeking Orthodontic Treatment at Medical Colleges \& Teaching Hospitals of Chitwan, Nepal. Orthodontic Journal of Nepal. 2018;8(2):41-4.

19. Singh JP. The contemporary Indian family. Handbook of world families. 2005:129-66.

20. DiBiase AT, Sandler PJ. Malocclusion, orthodontics and bullying. Dent Update. 2001;28(9):464-6.

21. Basit M, Sajjad SH, Khan MI, Ali A, Kurshid SK. Spatio-Temporal Trends of Urban Population in Pakistan. Asian Journal of Multidisciplinary Studies. 2018;6:8. 